\title{
The Effect of Cooperative Learning Model-Jigsaw Type towards High School Students Achievement on History Subject in Pekanbaru
}

\author{
Isjoni \\ Universitas Riau \\ Riau, Indonesia \\ isjoni@yahoo.com \\ Hasnah Faizah \\ Universitas Riau \\ Riau, Indonesia
}

\author{
Kamaruddin \\ Universitas Riau \\ Riau, Indonesia
}

\begin{abstract}
The aim this study is to find the effect of cooperative learning and conventional learning models on the history subject achievement of SMA 2 and SMA 4 students in Pekanbaru city. Besides, this research is also intended to find out the perception of both students and teachers about cooperative learning. The dependent variable is students taught by using cooperative learning model $(\mathrm{N}=72)$ and the independent variable is taught by traditional learning model $(\mathrm{N}=72)$. The pre-test was given at the first time, and post-test was 16 weeks after. There are six research instruments. The collected data were analyzed by using SPSS version 13. In addition, conte nt analysis was used to find the differences between cooperative and traditional learning models. The results showed that there were differences between cooperative and traditional learning approach. However, $t$ analysis showed that there were no differences between cooperative and conventional learni ng. Then, the content analysis show ed that most students prefer working in a group, meaning that cooperative learning was better than conventional learning. Based on the data analysis and its findings, the conclusion and suggestion were no different student's scores of history subject taught with jigsaw cooperative learning model and conventional model, there was a significantly different learning achievement based on pre-test and post-test of the students taught with jigsaw cooperative model in SMAN 2 and SMAN 4 Pekanbaru.
\end{abstract}

Keywords- Jigsaw; cooperative learning; learning achievement; history subject

\section{INTRODUCTION}

There are a number of factors making education successful such as teachers, students, and learning models. Teachers: They should have skills in teaching, in selecting learning models which enable students to get a success. Students: As targets of learning process until students have learning outcomes in learning, provided with good attitudes toward learning, encouraged to be critical thinkers and problem solvers, and pushed to practice social life among them.
Learning models: is a model or strategy used by teachers in teaching to improve students learning achievement.

A research conducted by Isjoni [1] reveals that students show poor attitude toward history subject for the teachers and their ways of teaching are so boring that the students learning achievement become low or unsatisfied, history teachers are unable to make students actively involved in the process of teaching and learning [10]. Students learning achievement also depends on the teaching methods used by teachers [12].

According to Marzano state that teaching and learning process as mentioned above will not be able to develop critical thinking, metacognitive, and creativity of students [13]. Therefore, teachers must always realize that the teaching method should be able to develop students' activities and creativity.

Ref. [2] has already introduced student-center learning, popularly called 'Cooperative Learning". Ref. [3] cooperative learning was designed and aimed to make students more actively involved in both interaction and communication in groups. In such groups discussion, students can solve learning problems by sharing ideas and giving feedback. Davidson and Kroll [4] state that cooperative learning benefits students very much in terms of such aspects as knowledge, skills, attitudes, concepts, pride, social communication, psychology, acceptability and rescpect for others in the groups.

According to the results of observation is known between the causes of students less interest and successfully learn the subjects of history is because teachers use the method of memorization and by using the lecture method. This learning model is also called the traditional or conventional learning model. One of the conventional methods is the lecture learning model. Sagala [5] states the learning model of the lecture is a form of interaction through the lighting and verbal narrative of the teacher to the students, this learning model as an activity to provide information with words often obscured and sometimes misinterpreted. Because the teacher is not very good at 
conveying information and maybe his students do not want to hear the teachings of his teachers.

The teaching of History can be challenging experience due to the abstract nature of the subject. The abstractness lies in the fact that events in the past cannot be reproduced and reexamined for authenticity, and motives for which actions were taken are not open to physical examination and scrutiny[10]. Historical teachers only tell or convey information, when students only accept, record and memorize the material given. History is a complex task encompassing the transformation of subject matter into a form that enables learners to gain meaning, while at the same time, retaining the integrity of the subject [6].

Many teachers are still familiar with the traditional teaching model, as a result of this learning process, students appear less passionate to learn in the classroom [14]. Students get bored because they are not actively involved.Cooperative learning can train students to have social skills, improve academic ability, improve learning outcomes, establish friendly relationships, learn from various sources of information, learn by using courtesy, improve student learning outcomes, improve attitudes less praised for school, learning to reduce bad behavior and to help students appreciate the opinions of others [3].

Three main concepts that characterize cooperative learning. Three characteristics of cooperative learning: Group awards, individual responsibility and equal opportunity[2]. Group awards, which are rewards or incentives to students have shown activity and creativity in the group. Individual accountability is the result of student learning that is influenced by the student's own ability. Individually students have two responsibilities, namely to do and understand the material, both for the results of his learning and learning outcomes group. Equal opportunity to succeed, every individual in the group is required to be jointly responsible for their learning to be more successful.

Cooperative learning could improve significantly students learning achievement and bring about their critical thinking [7]. Working together in groups gives chances to share ideas and experiences, speak up, and make choice. Besides, that cooperative learning could improve significantly students learning achievement in relation to the mastery of learning materials, active and interactive learning atmosphere in which teachers teach them pleasantly and could develop social skill and creative thinking of students that their academic learning achievement improves as well.

Cooperative Jigsaw II is one of the types of cooperative learning is a cooperative learning model that encourages students to actively and assist each other in mastering the material to achieve maximum learning outcomes [11]. The jigsaw type cooperative learning model is a cooperative learning model in which students learn in small groups of 4-6 people heterogeneously and working together with positive interdependence and responsible for the completeness of the part the subject matter to be learned and submitting the material to the members another group [8]. Each member of the group must be responsible for the completeness of the student material part that should be discussed and submitted the material to the original group members.

The Jigsaw cooperative learning model was also introduced by Eliot Aronson and his colleagues a cooperative learning strategy whereby each student becomes an expert in a particular field [9]. Then (sharing his knowledge) to other members of his group so that everyone can ultimately master the concepts. Therefore, cooperative learning as a group learning that requires the application of student-centered, humanistic and democratic learning approaches adapted to the students' ability and learning environment, so as to obtain the maximum learning result of the history lesson.

The aims of the study are to see the difference of the cooperative learning model to the students' learning outcomes in the subjects of History. The problem is formulated as "Is there any significantly different achievement of students taught with jigsaw cooperative type and that of those with conventional learning model?

The hypotheses are as follows;

Ho: There is no significant different students' achievement taught with jigsaw cooperative model and that of those with conventional learning model.

Sub-hypothesis:

Hoa: There is no significant different students' achievement taught with

jigsaw cooperative learning model and that of those with conventional learning model.

$\mathrm{H}_{0} \mathrm{~b}$ : There is no significant different result of pre and post-test of students taught with jigsaw cooperative model and that of those with conventional learning model.

$\mathrm{H}_{0} \mathrm{c}$ : There is no significant different learning the result of pre and post-test of students taught with jigsaw cooperative model and that of those with conventional learning model in SMAN 2 Pekanbaru.

$\mathrm{H}_{0 \mathrm{~d}}$ : There is no significant different learning achievement based on pre and post-test of students taught with jigsaw cooperative model and that of those with conventional learning model in SMAN 4 Pekanbaru.

The test of the learning result was given back to the students as this subject that aims to measure the success of learning. Students' learning outcomes in historical subjects are measured through the learning outcomes of the learning outcomes of the subjects of history at each meeting and the learning is carried out by the teacher, both for the experimental and control class. A pre-test is done before the teacher conducts the learning and post-test are done after the teacher completes the learning. Pre-test aims to know the impression of students to the material that has not been taught to students, and post exams carried out to find out how far the impression of students to the material that has been studied, students. This question is made by the teachers of both pre and post subjects in each school, based on the target history curriculum set by the Ministry of National Education. The problem form is open to the following topics : 
1. The development of Islam in Indonesia

2. The coming and colonialism of European in Indonesia

3. The influences of new interpretations on national move

Post-test was given to both experiment and control classes and measured by looking at aspects of knowledge, comprehension, application, analysis, synthesis, and evaluation.

\section{METHOD}

The population of this study is grade 11th of Social Science (IPS) students in Senior High Schools (SMA) Pekanbaru city with "A" accreditation. This topic of history was given in the first semester. The samples of the study were students of SMA 2 and SMA 4 Pekanbaru. SMA 2 consisted of four classes and SMA 4 three classes. Class determination for both experiment and control classes was conducted by statistical test, namely Bartlet Test, especially for the variant homogeneity of each class. Two classes were taken for experiment and control groups from each school.The study involved 151 students of class 11 of the social science department, 67 males $(44,37 \%)$ and 84 females $(55,63 \%)$. In this case, conventional group consisted of 72 students, 28 males $(38,89 \%)$ and 44 females $(61,11 \%)$. Meanwhile, jigsaw cooperative learning model group consisted of 79 students, 39 males $(49,36 \%)$ and 40 females $(50,64 \%)$.

\section{RESULT}

\section{A. Description of Pre-Test and Post-Test Result}

Table 1. refers to the standard of deviation (s.d) for pre-test and post-test of learning achievement on history subject by applying both cooperative and conventional models.

TABLE I. MINIMUM SCORES OF PRE-TEST AND POST-TEST FOR LEARNING ACHIEVEMENT

\begin{tabular}{|l|c|c|c|c|}
\hline \multirow{2}{*}{ Variable } & \multicolumn{2}{|c|}{ Pre-test } & \multicolumn{2}{c|}{ Post-test } \\
\cline { 2 - 5 } & $\mathbf{C}_{\mathbf{1}}$ & $\mathbf{C}_{\mathbf{2}}$ & $\mathbf{C}_{\mathbf{1}}$ & $\mathbf{C}_{\mathbf{2}}$ \\
\hline Average & 72,92 & 77,57 & 86,30 & 76,99 \\
\hline Modus & 70 & 70 & 80 & 80 \\
\hline Median & 73 & 80 & 85 & 80 \\
\hline Maximum & 60 & 90 & 100 & 95 \\
\hline Minimum & 90 & 50 & 65 & 50 \\
\hline S.d & 5,20 & 9,42 & 7,90 & 9,67 \\
\hline Combined rate & \multicolumn{3}{|c|}{75,14} & \multicolumn{3}{|c|}{81,86} \\
\hline Combined S.d & \multicolumn{3}{|c|}{7,51} & \\
\hline Note : C $_{1}=$ Cooperative Learning Model \\
C $_{2}=$ Conventional Learning Model \\
\hline
\end{tabular}

Table 1 showed that pre-test scores of history learning achievement variable, the lowest score is 50 and the highest is 90. The average is 75,14 ( $\mathrm{s} . \mathrm{d}=7,51$ ) by using 20 multiple choice questions. Meanwhile,post-test scores of history learning achievement variable, the lowest score is 50 and the highest is 100 . The average is $81,86(\mathrm{~s} . \mathrm{d}=8,79)$ by using 5 essay questions.

\section{B. Analysis of Variable for Students of SMAN 2 and SMAN 4 Pekanbaru}

In SMAN 2 Pekanbaru, 34 students were in conventional learning group and 39 in the cooperative group. As variable of students learning achievement in the cooperative group, the lowest score was 65 and the highest was 100 . The average was 86,61 (s.d = 8,42). Meanwhile, in the conventional group, then the lowest score was 50 and the highest was 90. The average was $73,52($ s.d $=11,38)$.

TABLE II. LEARNING ACHIEVEMENT POST-TEST OF StUdENTS IN SMAN 2 PEKANBARU

\begin{tabular}{|c|c|c|c|}
\hline Variable & Cooperative & Conventional & Totality \\
\hline Average & 86,61 & 73,52 & 80,07 \\
\hline Minimum & 65 & 50 & \\
\hline Maximum & 100 & 90 & \\
\hline (S.d) & 8,42 & 11,38 & 8,53 \\
\hline
\end{tabular}

To determine whether there is a difference or not between students in the group of jigsaw cooperative learning model and those of in conventional model in SMAN 2 Pekanbaru, the researc her used t-test on. A t-test on learning achievement variable indicates a significant difference, where $t$ hitung=6,214> ttabel=2,326, which means H0 is rejected.

For the average score of students learning achievement on history subject in SMAN 4 Pekanbaru, the lowest score was 75 and the highest was 100. The average was 86 (s.d =7,44). Meanwhile, of those in the conventional group, the lowest score was 65 and the highest was 90 . The average was 80,07 $(\mathrm{s} . \mathrm{d}=6,57)$.

TABLE III. LEARNING ACHIEVEMENT POST-TEST OF COOPERATIVE GROUP OF STUDENTS IN SMAN 4 PEKANBARU

\begin{tabular}{|l|c|c|c|}
\hline Variable & Pre-test & Post-test & $\begin{array}{c}\text { Totality } \\
\text { Rate }\end{array}$ \\
\hline Average & 72,92 & 86,31 & 79,62 \\
\hline Minimum & 60 & 65 & \\
\hline Maximum & 90 & 100 & \\
\hline (S.d) & 5,20 & 7,89 & 6,55 \\
\hline
\end{tabular}

To determine whether there is or not a difference between students in the group of jigsaw cooperative learning model and those of in conventional model in SMAN 4 Pekanbaru, the writer used t-test on. A t-test on learning achievement variable indicates a significant difference, $t$ hitung=2,14> ttabel=2,326, which means $\mathrm{H} 0$ is rejected. And as learning achievement variable, there is a significant difference, where $t_{\text {hitung }}=3,715>t_{\text {tabel }}=2,326$, which means HOb is rejected.

Variable Analysis for Differences between Pre-test and Post-test Treatment in the Group of students Using Jigsaw Cooperative Learning Model in SMAN 2 Pekanbar u.

To describe pre-test and post-test of students using jigsaw cooperative learning model in SMAN 2 Pekanbaru, the lowest pre-test score for learning achievement variable is 60 , the highest is 82 and the mean is 71,95 (s.d=5,87). Meanwhile, the 
lowest post-test score is 55 , the highest is 100 and the mean is 86,62 (s.d=8,42). This means there is an improvement resulted from the pre-test and post-test treatment using jigsaw cooperative learning model.

TABLE IV. VARIABLE DETERMINING DifFERENCES BETWEEN PRE-TEST AND POST-TEST

\begin{tabular}{|l|c|c|}
\hline \multicolumn{1}{|c|}{ Variable } & Pre-test & Post-test \\
\hline Average & 71,94 & 86,62 \\
\hline Minimum & 60 & 55 \\
\hline Maximum & 82 & 100 \\
\hline (S.d) & 5,87 & 8,42 \\
\hline
\end{tabular}

To determine whether or not there is a difference between pre-test and post-test for each variable in the group of jigsaw cooperative learning model in SMAN 2 Pekanbaru, the researcher used t-test on. A t-test on learning achievement variable indicates a significant difference, where $t_{\text {hitung }}=16,0>$ $\mathrm{t}_{\text {tabel }}=2,326$, which means $\mathrm{HO}$ is rejected.

In order to make an analysis between pre-test and post-test scores, the writer needs to know first the homogeneity of a variant variable to find out whether or not there is such a difference as mentioned above in the group of jigsaw cooperative learning model in SMAN 2 Pekanbaru. So, the writer conducted Fisher-Test (F-Test) on. As a variable, learning achievement of students is found Fhitung $=0,697$, Ftabel that is $F(38,38)=1,71$. This result is meaningful and indicates that there is no different learning achievement between the two groups of students.

Variable Analysis for Differences between Pre-test and Post-test Treatment in the Group of Students Using Jigsaw Cooperative Learning Model in SMAN 4 Pekanbaru.

To describe pre-test and post-test of students using jigsaw cooperative learning model in SMAN 4 Pekanbaru, the lowest pre-test score for learning achievement variable is 70 , the highest is 90 and the mean is 73,88 (s.d=4,31). Meanwhile, the lowest post-test score is 75 , the highest is 100 and the mean is 86,00 (s.d=7,44). This means there is an improvement resulted from the pre-test and post-test treatment using jigsaw cooperative learning model in SMAN 4 Pekanbaru.

TABLE V. VARIABLE DETERMINING DiFFERENCES BETWEEN PRE-TEST AND POST-TEST

\begin{tabular}{lcc}
\hline \multicolumn{1}{c}{ Variable } & Pre-test & Post-test \\
\hline Average & 73,88 & 86,00 \\
Minimum & 70 & 75 \\
Maximum & 90 & 100 \\
(S.d) & 4,31 & 7,44 \\
\hline
\end{tabular}

To determine whether there is or not a difference between pre-test and post-test for each variable in the group of jigsaw cooperative learning model in SMAN 4 Pekanbaru, the researcher used t-test on. $\alpha=0,01 \mathrm{~A}$ t-test on learning achievement variable indicates a significant difference, where $\mathrm{t}_{\text {hitung }}=11,31>\mathrm{t}_{\text {tabel }}=2,326$, which means $\mathrm{H}_{0}$ is rejected.
In order to make an analysis between pre-test and post-test scores, the writer needs to know the homogeneity of a variant variable, to find out whether or not there is such a difference as mentioned above in the group of jigsaw cooperative learning model in SMAN 4 Pekanbaru. So, the writer conducted Fisher-Test (F-Test) on $\alpha=0,05$. As a variable, learning achievement of students is found $F_{\text {hitung }}=0,579, F_{\text {tabel }}$ that is $F(39,39)=$ 1,74 . This result is meaningful and indicates that there is no different learning achievement between the two groups of students.

\section{Test Result of Hypothesis}

The research hypothesis was tested by statistical data. Each hypothesis is presented and followed by result discussions.

$\mathrm{H}_{0}$ : There is no significant different learning achievement of students taught with jigsaw cooperative type and that of those with conventional learning model

After statistically analyzed, the finding is a significant different achievement of students taught by cooperative model and of those taught by conventional learning model. For this reason, null hypothesis or $\mathrm{H}_{\mathrm{o}}$ is rejected.

$\mathrm{H}_{0 \mathrm{a}}$ : There is no significant different learning achievement of students taught with jigsaw cooperative model and that of those with conventional learning model in SMAN 2 Pekanbaru.

After statistically analyzed, the finding that there is a significant different achievement of students taught by cooperative model and by conventional learning model in SMAN 2 Pekanbaru. For this reason, null hypothesis or $\mathrm{H}_{\mathrm{o}}$ is rejected. In other words, there is a significant different achievement of students taught with cooperative model and of those taught by conventional learning model

Hob : There is no significant different learning achievement between pre-test and post-test of the students taught with jigsaw cooperative learning model and that of those with conventional learning model.

After statistically analyzed, the result showed that there is a significant different achievement of students taught with cooperative model and of those taught with conventional learning model. For this reason, null hypothesis or $\mathrm{H}_{0}$ is rejected. In other words, there is a significant different achievement of students taught by cooperative model and of those taught with conventional learning model

$\mathrm{H}_{0} \mathrm{c}$ : There is no significant different learning achievement based on of pre-test and post-test between students taught with jigsaw cooperative model and that of those with conventional learning model.

The result of statistical analysis shows that there is a significantly different learning achievement based on and posttest of students taught with jigsaw cooperative learning model.

$\mathrm{H}_{0 \mathrm{~d}}$ : There is no significant different learning achievement based on pre-test and post-test between students taught with jigsaw cooperative model and that of those 
with conventional learning model in SMAN 2 Pekanbaru.

The result of the statistical analysis shows that there is a significant different learning achievement of the students taught with jigsaw cooperative model and that of those with conventional learning model in SMAN 2 Pekanbaru. For this reason, null hypothesis or $\mathrm{H}_{\mathrm{o}}$ is rejected. In other words, there is a significant different achievement based on pre-test and post-test of students taught with cooperative model and of those taught with conventional learning model.

$\underline{\mathrm{H}}_{0 \mathrm{e}} \quad$ : There is no significant different learning achievement based on of pre-test and post-test between students taught with jigsaw cooperative type and that of those with conventional learning model in SMAN 4 Pekanbaru.

The result of the statistical analysis showed that there is a significantly different learning achievement based on pre-test and post-test of the students taught with jigsaw cooperative model in SMAN 2 and SMAN 4 Pekanbaru

\section{CONCLUSION AND SUGGESTION}

\section{A. Conclusion}

Established on the analysis data, it can be concluded that: (1)there is no different student's scores of history subject taught with jigsaw cooperative learning model and of those with conventional model and null hypothesis or Ho is rejected; (2)there is a significantly different achievement of the students in the group of jigsaw cooperative learning and conventional learning model at SMAN 2 Pekanbaru; (3) there is a significantly different learning achievement based on pre-test and post-test of the students taught with jigsaw cooperative model in SMAN 2 and SMAN 4 Pekanbaru.

\section{B. Suggestion}

From the author's point of view, for implementation of learning models for students will be more maximum if adding more observers in lesson meeting. This will facilitate discussion between students and groups, affective, and psychomotor for each student can be monitored properly. Besides that, $t$ he need for advanced research approach to see its effectiveness with the application of other learning mode

\section{REFERENCES}

[1] Isjoni. Pelaksanan Pembelajaran Mata Pelajaran Sejarah di Kaitkan dengan Prestasi Belajar Siswa SMA. Proyek Penelitian UNRI Pekanbaru. (2000)

[2] Slavin, R. E. Cooperative Learning: Theory, Research, and Practice. Johns Hopkins University: United States. (2016)

[3] Johnson, D.W. \& Johnson, R.T. Learning together and alone: cooperative, Competitive, and individualistic learning. Boston: Allyn and Bacon. (1991)

[4] Davidson \& Kroll, J. An overview of research on cooperative learning related mathematics. Journal for research in Mathematics Education 22: 362-365. (1991)

[5] Sagala, S. 2003. Konsep dan makna pembelajaran. Bandung: Alpabeta.

[6] Taylor, T. \& Young, C. Making history: A Guide for the teaching and learning of history in Australian schools.Canberra: Commonwealth of Australia.(2003)
[7] Shwalb, Barbara J and David W. Shwalb. 1995. Cooperative Learning in Cultural Contexts: An Integrated Review.23 (1995) International Journal of Educational Research, page 293-300.

[8] Arends, Richard. 2007. Learning to Teach. Pustaka Pelajar. Yogyakarta.

[9] Aronson, E., dkk. 1978. The Jigsaw Classroom. Beverly Hills, CA: Sage Publications, Inc.

[10] G. Boadu. Effective Teaching in History: The Perspectives of History Student-Teachers. International Journal of Humanities and Social Sciences. 3 (1) (2017) 38-51.

[11] G. Çağatay, G Demircioğlu. The Effect Of Jigsaw-I Cooperative Learning Technique On Students' Understanding of Basic Organic Chemistry Concepts. Educational Research Association The International Journal of Educational Researchers, 4(2) (2013) 30-37.

[12] Zahorik, John. Constructivist teaching (fastback 390). Bloomington, Indiana: Phi-Delta Kappa Education Foundation.(1995).

[13] E. Zakaria, T Solffitri, Y Daud, Z Abidin. Effect of cooperative learning on secondary school students' mathematics achievement. Creative education. 4(2) (2014) 98-100. doi:10.4236/ce.213.42014. 